\title{
Interaction between Cadmium and Zinc Levels in the Biological Samples of Type 1 Diabetic Mellitus Children, Reside in Different Areas of Sindh, Pakistan
}

\author{
Anjum Lashari $\mathbb{D}^{\circledR}$, Hassan Imran Afridi $\left.{ }^{(}\right)$, Tasneem Gul Kazi ${ }^{\circledR}$, Farah Naz Talpur $\left.{ }^{(}\right)$,

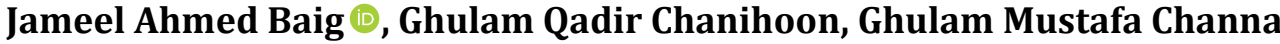 \\ National Centre of Excellence in Analytical Chemistry, University of Sindh, Jamshoro, Pakistan \\ Email: anjum.lashari@scholars.usindh.edu.pk, hassan.afridi@usindh.edu.pk, tasneem.kazi@usindh.edu.pk, \\ farah.talpur@usindh.edu.pk, jameel.baig@@usindh.edu.pk
}

How to cite this paper: Lashari, A., Afridi, H.I., Kazi, T.G., Talpur, F.N., Baig, J.A., Chanihoon, G.Q. and Channa, G.M. (2021) Interaction between Cadmium and Zinc Levels in the Biological Samples of Type 1 Diabetic Mellitus Children, Reside in Different Areas of Sindh, Pakistan. American Journal of Analytical Chemistry, 12, 241-259. https://doi.org/10.4236/ajac.2021.126015

Received: May 14, 2021

Accepted: June 21, 2021

Published: June 24, 2021

Copyright $\odot 2021$ by author(s) and Scientific Research Publishing Inc. This work is licensed under the Creative Commons Attribution International License (CC BY 4.0).

http://creativecommons.org/licenses/by/4.0/

\begin{abstract}
Type 1 Diabetes mellitus (T1DM) is one of the familiar childhood immunemediated onsets and can lead to early mortalities and morbidities. It can arise at any stage, but the peak of occurrence is reported less than 18 years of age. T1DM cases in Pakistan were less than $2 \%$ of the total diabetic population. The current work designed to assess the concentration of cadmium (Cd) and zinc (Zn) in blood, scalp hair and serum samples of T1DM children, age ranged 1 14 years of both genders. For comparison purpose, the age-matched referent subjects of both genders were tested. The microwave-assisted acid digestion procedure was used to determine the elemental analysis in the biological samples of T1DM children and referent subjects. The resulted data of certified reference material of blood, scalp hair, and serum validated the certainty of the designed method. The analysis of $\mathrm{Zn}$ was performed by flame atomic absorption spectrometry, while the Cd contents were determined by electrothermal atomic absorption spectrometry. T1DM affected children of both genders have lower $\mathrm{Zn}$ level in the blood, scalp hair, and serum samples. Whereas, the levels of $\mathrm{Cd}$ were found to be higher in the biological samples of T1DM affected children as compared to referent subjects. The finding of the current study is a significant hypothesis for medical experts, to diagnose the deficiency of essential $(\mathrm{Zn})$ and toxicity of heavy/toxic element $(\mathrm{Cd})$ in the biological specimen of T1DM affected children.
\end{abstract}

\section{Keywords}

Zinc, Cadmium, Biological Samples, Type 1 Diabetic Mellitus, Children 


\section{Introduction}

Diabetes Mellitus (DM) is a global issue. It is the most important cause of morbidity and mortality all over the world. Diabetes is related to high rates of blindness, hospitalization, renal failure, and non-traumatic amputation [1]. The elevated incidences of DM may cause by unhealthy lifestyles, maternal or fetal malnutrition, and genetic factors. Limited physical activity is a major risk for the prevalence of DM. The other risk factors of DM may include obesity and high caloric intake [2] [3]. The DM is mainly divided into two types of diabetes. Type 1 Diabetes Mellitus (T1DM) is insulin-dependent, occurs in childhood, results in partial or complete damage of the insulin-producing beta cells ( $\beta$-cells) and Type 2 DM (non-insulin dependent) happens in adulthood, caused by insulin resistance or insulin shortage [1]. T1DM is one of the frequent immune-mediated childhood diseases and can cause early mortalities/morbidities [4]. T1DM can happen at any age, although the peak occurrence is observed under 18 years of age [5] [6]. Genetic factor and vulnerability of certain viruses may contribute to T1DM. The major risk factors for DM are identified as the positive family history, age, and fatness especially central obesity [7] [8]. The clinical presentations of T1DM in children and adolescence have merged increasingly over recent years. Conventionally, T1DM is described as an uncommon disorder of autoimmune origin, presenting acutely with ketosis, thirst, and polyuria and weight loss in a child [9]. Diabetic nephropathy is the major imperative reason for death in T1-DM patients, compared to T2DM. The occurrence of T1-DM is more than the individual's 20 cases/y/one million individuals [10].

Trace metals in T1DM patients are evidence to alter human metabolism. Moreover, these trace metals may have a key role in the progression and pathogenesis of such syndrome [10]. The role of trace element and micronutrients is optimal for metabolic function in human beings and supplies a diversity of functions including regulatory, catalytical and structural mechanisms in which, they act together with macromolecules such as enzymes, presecretory, prohormones, granules, and biological membranes [10].

Trace elements have a principal role in the prevalence of T1DM. $\mathrm{Zn}$ is an important micronutrient with the major role in the synthesis, storage, secretion, and function of insulin. Its metabolic function is altered in diabetes [11]. Zn deficiency is correlated with insulin resistance [12]. In diabetic patients, chronic hyperglycemia is due to glycosylation and peroxidation leads to increased oxidative stress and thereby proteins and lipids structure are changed [13].

The intake of toxic elements may promote DM, hypertensive and atherosclerosis disorders by increasing oxidative stress due to the deficiency of $\mathrm{Zn} \mathrm{[14].}$ The deficiency of essential nutrients, lack of homeostatic control or an excess intake of some toxic elements causes chronic physiological disorders [15]. The toxic metals can interfere with the normal functioning of essential trace elements in the enzymatic systems. The toxic metals can be replacing the nutritional minerals in the enzymes and inactive to them. Whereas, a higher dietary level of essential minerals and vitamins helps to prevent toxic metal toxicity, as well as 
helps to eliminate them from the body [15]. Metal ions bonded to melanosomes according to atomic weight and volume. Heavy metals can effectively compete to same binding sites as foreign ions to replace previously bound metals [15]. However, these bonded heavy metals cannot easily manageable to displacement [16]. The Cd is an inhibitor of the enzymes with sulfhydryl groups and disrupts the pathways of the oxidative metabolism [17]. These facts were also confirmed by in vitro studies, reported elsewhere [18].

To keep in view of these facts, it is necessary to analyze the essential trace and toxic elemental concentrations in the biological samples of T1DM children, and to monitor their impact on the human metabolism. In many cases, whole blood, serum, plasma, and urine were analyzed [19] [20] [21]. The atomic absorption spectrometry (AAS) is mostly used for the clinical assay due to their specificity, sensitivity, precision, simplicity, and relatively low cost per analysis [22]. Hair analysis has many advantages as compared to serum, blood or other body fluids such as it is easily collected, stable on storage and has a higher concentration of elements, but many individuals and external factors can influence element levels [23] [24].

The rate of T1DM has been increasing worldwide over the last ten years [25]. Pakistan numbered 6th among the list of top ten countries having highest burden of DM. More than $10 \%$ of the adult population of Pakistan from 185 million populations is the witness of diabetes. Similarly, an equivalent quantity of inhabitants is suffering from improper glucose tolerance (IGT) [26].

Among children aged up to 16 years, the occurrences of diabetes are found to be merely 1.02/100,000 per year in Pakistan [27]. A published research study by the DIAMOND Project Group confirms that the low-frequency rate of T1DM in Pakistan are barely accessible particularly concerning medical presentation counting Diabetic ketoacidosis (DKA) and unrelieved complications. It is primarily because of deficient in appropriate health care system in Pakistan [27].

The main objective of this study was to evaluate zinc and cadmium concentrations in the biological samples (scalp hair, blood, and serum) of T1DM and referent children of both genders, ages ranged between $(1-14)$ years.

\section{Materials and Methods}

\subsection{Instrumentation}

Biological samples were digested through a domestic microwave oven, PEL (Osaka, Japan) (maximum heating power of $900 \mathrm{~W}$ ). The elemental analysis was carried out by means of A. Analyst 700, Perkin Elmer (Norwalk, CT, USA) atomic absorption spectrometer, equipped with deuterium background correction, and graphite furnace HGA-400 (Perkin Elmer), laminar flame burner a pyrocoated graphite tube with an integrated platform and an autosampler AS-800 (Perkin Elmer). Table 1 shows the operating condition of the atomic absorption spectrometer. The Cd was measured by electrothermal atomic absorption spectrometry (ETAAS), whilst flame atomic absorption spectrometry 
Table 1. Measurement conditions for electrothermal atomization AAS 700.

\begin{tabular}{|c|c|c|c|}
\hline Parameters & Cadmium & Zinc & \\
\hline Lamp current $(\mathrm{mA})$ & 6.0 & 7.5 & \\
\hline Wave length $(\mathrm{nm})$ & 228.8 & 214.0 & \\
\hline Slit-width (nm) & 0.7 & 0.7 & \\
\hline Drying temp $\left({ }^{\circ} \mathrm{C} / \mathrm{ramp} / \mathrm{hold}(\mathrm{s})\right.$ & $140 / 15 / 5$ & $\begin{array}{l}\text { Burner height } \\
\quad(\mathrm{mm})\end{array}$ & 7.5 \\
\hline Ashing temp $\left({ }^{\circ} \mathrm{C} / \mathrm{ramp} / \mathrm{hold}(\mathrm{s})\right.$ & $850 / 10 / 20$ & $\begin{array}{c}\text { Oxidant (Air) } \\
\text { L/min }\end{array}$ & 17 \\
\hline Atomization temp $\left({ }^{\circ} \mathrm{C}\right) / \mathrm{ramp} /$ hold $(\mathrm{s})$ & $1650 / 0 / 5.0$ & $\begin{array}{c}\text { Fuel (Acetylene) } \\
\mathrm{L} / \mathrm{min}\end{array}$ & 2 \\
\hline Cleaning temp $\left({ }^{\circ} \mathrm{C}\right) / \mathrm{ramp} /$ hold $(\mathrm{s})$ & $2600 / 1 / 3$ & & \\
\hline Chemical modifier & $\mathrm{Mg}\left(\mathrm{NO}_{3}\right)_{2}+\mathrm{Pd}\left(\mathrm{NO}_{3}\right)_{2}$ & & \\
\hline \multicolumn{4}{|c|}{ Sample volume $(10 \mu \mathrm{l})$, Cuvette $=$ Cup, Carrier gas $=(200 \mathrm{ml} / \mathrm{min})$} \\
\hline
\end{tabular}

(FAAS) with an air-acetylene flame was used for the analysis of $\mathrm{Zn}$. In flame absorption mode, absorbance peaks were measured as signals, while in the graphite furnace (peak area), integrated absorbance values were determined. Acid-washed polytetrafluoroethylene (PTFE) vessels and flasks were used for preparation and storage of standard and solutions.

\subsection{Reagents and Standard Solutions}

Water system of ELGA, ELGA Lab (Bucks, UK) was used to obtain ultrapure water during the laboratory work. Strong acids, (65\%) $\mathrm{HNO}_{3}$ and $(30 \%) \mathrm{H}_{2} \mathrm{O}_{2}$, were purchased from Merck (Darmstadt, Germany). Standard solutions of Cd and Zn, Fluka Kamica (Buchs, Switzerland), were used by stepwise dilution of certified standard solutions of each elements of thousand ppm with $0.2 \mathrm{M} \mathrm{HNO}_{3}$ before analyzing the sample solution. At $4^{\circ} \mathrm{C}$, PTFE bottles were used to stock up the solutions. Certified reference materials (CRMs) of Clincheck Control Lyophilized $^{\circledR}$ human blood Recipe (Munich, Germany), Clincheck Control Lyophilized $^{\circledR}$ human serum Recipe (Munich, Germany) and certified human hair BCR 397, purchased from Bureau of References of European Communities (Brussels, Belgium), were used for the accuracy of methodology. Glass apparatus and plastic materials were soaked for $24 \mathrm{~h}$ in $0.2 \mathrm{M} \mathrm{HNO}_{3}$, were used throughout the experimental work. Deionized distilled water were used for washing the glass and plastic apparatus, then finally rinsed with Milli-Q water. After this, glass apparatus were dried and stored in a class 100 laminar flow hoods.

\subsection{Diabetic Mellitus Type 1 Children and Medical Treatment Methodology}

Before initial this study, the approval was obtained from ethical review committee of the University of Sindh, Jamshoro, Pakistan. 


\subsection{Study Population}

The study conscripted T1DM children from different hospitals of Hyderabad and Jamshoro district from January 2016 to June 2016. The blood, scalp hair and serum sample of 194 control and 84 T1DM children of both genders were predominantly collected (Table 2). For all the controls and T1DM children, anthropometric parameters, comprising weight, height, BMI, WBC's, RBC's, Glucose, $\mathrm{HbA1C}$, platelets, platelet distribution width, mean platelet volume, were recorded using standard protocol (Table 3). In order to collected particulars regarding health, ethnic origin, duration of diabetes, dietary habits, physical data age and consent, a questionnaire was employed. The guardians/parents of children, who were enrolled in the study, provided their written consent. They were orally explained the purpose of the study in their native language along with an approval form as most of the study subjects belong to poor uneducated families.

The selection criteria of 194 referent children of both genders belong to the same qualities with respect to age group, socio-economic status and dietary habits, not suffering from any physiological disorders. These children were generally the healthy family members of the diabetic mellitus type 1 children. Before collection of biological samples, referent children have undergone a standard routine medical examination. Questionnaire was also used to get the information related with dietary habits and socioeconomic conditions along in details, mentioned in Table 4.

\subsection{Biological Samples}

\subsubsection{Collection of Blood \& Serum Samples}

Heparinized Lithium Vacutainer ${ }^{\circledR}$ tubes (B Becton Dickinson, Rutherford, USA) $\{10 \mathrm{~mm}\}$ were used for the collection of venous blood samples $(7 \mathrm{~mL})$ between 9:30 and 11:00 a.m. About $2 \mathrm{~mL}$ of blood samples were sent to hospital pathological laboratories for biochemical tests using standard methods. $2 \mathrm{~mL}$ of venous blood samples were stored at $-20^{\circ} \mathrm{C}$ until elemental analysis, while the remaining $3 \mathrm{~mL}$ were used for separating the sera. The blood was allowed to clot at room temperature for 15 to 30 minutes. When the blood had clotted completely, it was then centrifuged for $5-10$ minutes at $2500 \mathrm{rpm}$. The supernatant fluid was then separated using a Pasteur pipette, labeled accordingly, and stored at $-20^{\circ} \mathrm{C}$ until analysis.

Table 2. The number of subjects as control and diabetic mellitus type 1 children.

\begin{tabular}{ccccc}
\hline \multirow{2}{*}{ Age groups } & \multicolumn{2}{c}{ Male } & \multicolumn{2}{c}{ Female } \\
\cline { 2 - 5 } & Controls & ${ }^{a}$ DM I & Controls & DM I \\
\hline $1-5$ & 25 & 14 & 22 & 12 \\
$6-10$ & 31 & 16 & 26 & 14 \\
$11-14$ & 51 & 15 & 39 & 13 \\
Total & 107 & 45 & 87 & 39 \\
\hline
\end{tabular}

Key: ${ }^{a}$ Diabetic Mellitus type-1. 
Table 3. Biochemical parameters in referents and diabetic mellitus type 1 children of both genders (mean \pm SD).

\begin{tabular}{|c|c|c|c|c|c|c|c|}
\hline \multirow{2}{*}{ Parameters } & \multicolumn{2}{|c|}{1 - 5 years } & \multicolumn{2}{|c|}{$6-10$ years } & \multicolumn{2}{|c|}{$11-14$ years } & \multirow{2}{*}{$\begin{array}{l}\text { Normal } \\
\text { range }\end{array}$} \\
\hline & Referents & $\begin{array}{c}\text { Diabetic mellitus } \\
\text { type } 1\end{array}$ & Referents & $\begin{array}{l}\text { Diabetic mellitus } \\
\text { type } 1\end{array}$ & Referents & $\begin{array}{c}\text { Diabetic mellitus } \\
\text { type } 1\end{array}$ & \\
\hline \multicolumn{8}{|c|}{ Male } \\
\hline Weight (kg) & $17.9 \pm 1.38$ & $14.3 \pm 1.08$ & $27.9 \pm 1.45$ & $23.5 \pm 1.32$ & $40.9 \pm 1.36$ & $33.6 \pm 0.95$ & -------- \\
\hline Height $(\mathrm{cm})$ & $94.9 \pm 3.17$ & $77.2 \pm 1.20$ & $125.3 \pm 2.68$ & $105 \pm 2.08$ & $151.7 \pm 1.95$ & $138.2 \pm 1.35$ & ---.---. \\
\hline BMI $\left(\mathrm{kg} / \mathrm{m}^{2}\right)$ & $19.7 \pm 0.85$ & $24.0 \pm 1.15$ & $17.7 \pm 1.24$ & $21.3 \pm 0.83$ & $17.8 \pm 1.60$ & $17.6 \pm 0.99$ & -------- \\
\hline $\mathrm{Hb}(\mathrm{g} / \mathrm{dL})$ & $11.9 \pm 0.42$ & $6.29 \pm 0.51$ & $12.6 \pm 0.95$ & $6.29 \pm 0.51$ & $12.3 \pm 0.50$ & $5.62 \pm 0.38$ & $11.5-14.8$ \\
\hline Hct (\%) & $35.6 \pm 1.35$ & $48.3 \pm 3.28$ & $37.5 \pm 1.02$ & $46.3 \pm 1.72$ & $36.9 \pm 1.41$ & $50.4 \pm 1.19$ & $35-55$ \\
\hline $\begin{array}{l}\text { Glucose } \\
(\mathrm{mmol} / \mathrm{L})\end{array}$ & $4.39 \pm 0.40$ & $6.50 \pm 0.37$ & $4.68 \pm 0.62$ & $7.43 \pm 0.52$ & $4.85 \pm 0.42$ & $8.16 \pm 0.50$ & $3.4-5.4$ \\
\hline$\% \mathrm{HbA} 1 \mathrm{C}$ & $4.37 \pm 0.50$ & $8.62 \pm 0.61$ & $4.82 \pm 0.48$ & $9.15 \pm 0.60$ & $4.65 \pm 0.35$ & $9.42 \pm 0.70$ & \\
\hline $\mathrm{RBC}\left(\mathrm{mm}^{3}\right)$ & $4.60 \pm 0.51$ & $3.05 \pm 0.19$ & $4.23 \pm 0.59$ & $2.95 \pm 0.48$ & $4.76 \pm 0.42$ & $2.64 \pm 0.35$ & $3.5-5.5$ \\
\hline $\mathrm{WBC}\left(\mathrm{mm}^{3}\right)$ & $6.42 \pm 0.62$ & $6.35 \pm 0.37$ & $7.05 \pm 0.43$ & $6.05 \pm 0.20$ & $7.38 \pm 0.62$ & $6.53 \pm 0.45$ & $3.5-10$ \\
\hline Platelets $\left(\mathrm{mm}^{3}\right)$ & $210 \pm 10.6$ & $235 \pm 9.52$ & $252 \pm 25.9$ & $298 \pm 19.5$ & $278 \pm 30.9$ & $316 \pm 20.6$ & $100-400$ \\
\hline $\begin{array}{l}\text { mean platelet } \\
\text { volume (fL) }\end{array}$ & $10.0 \pm 0.24$ & $10.7 \pm 1.03$ & $10.2 \pm 0.40$ & $11.0 \pm 0.39$ & $10.5 \pm 0.28$ & $11.8 \pm 0.57$ & \\
\hline $\begin{array}{l}\text { Platelet distribution } \\
\text { width [\%] }\end{array}$ & $11.5 \pm 0.96$ & $12.4 \pm 1.63$ & $11.9 \pm 0.52$ & $12.7 \pm 1.30$ & $11.7 \pm 0.30$ & $12.5 \pm 0.65$ & \\
\hline \multicolumn{8}{|c|}{ Female } \\
\hline Weight (kg) & $14.5 \pm 1.15$ & $12.6 \pm 0.98$ & $25.5 \pm 1.38$ & $21.9 \pm 1.06$ & $42.5 \pm 2.39$ & $35.9 \pm 1.24$ & -------- \\
\hline Height $(\mathrm{cm})$ & $93.0 \pm 4.02$ & $84.9 \pm 1.30$ & $127.8 \pm 2.08$ & $112.6 \pm 1.8$ & $151.7 \pm 1.44$ & $144.9 \pm 1.07$ & ---.---. \\
\hline BMI $\left(\mathrm{kg} / \mathrm{m}^{2}\right)$ & $16.8 \pm 1.21$ & $17.8 \pm 1.04$ & $15.6 \pm 1.05$ & $17.3 \pm 1.60$ & $18.5 \pm 1.35$ & $17.1 \pm 0.68$ & -------- \\
\hline $\mathrm{Hb}(\mathrm{g} / \mathrm{dL})$ & $11.7 \pm 0.31$ & $6.35 \pm 0.42$ & $12.5 \pm 1.05$ & $6.18 \pm 0.36$ & $11.9 \pm 0.48$ & $5.39 \pm 0.62$ & $11.5-14.8$ \\
\hline Hct (\%) & $36.4 \pm 0.89$ & $49.2 \pm 2.71$ & $36.9 \pm 0.87$ & $50.7 \pm 1.35$ & $38.2 \pm 1.58$ & $51.9 \pm 1.35$ & $35-55$ \\
\hline $\begin{array}{l}\text { Glucose } \\
(\mathrm{mmol} / \mathrm{L})\end{array}$ & $4.52 \pm 0.69$ & $6.79 \pm 0.52$ & $4.75 \pm 0.40$ & $7.62 \pm 0.70$ & $4.60 \pm 0.58$ & $7.95 \pm 0.72$ & $3.4-5.4$ \\
\hline$\% \mathrm{HbA} 1 \mathrm{C}$ & $4.24 \pm 0.37$ & $8.75 \pm 0.92$ & $4.59 \pm 0.35$ & $9.07 \pm 0.52$ & $4.48 \pm 0.47$ & $9.29 \pm 0.62$ & \\
\hline $\mathrm{RBC}\left(\mathrm{mm}^{3}\right)$ & $4.72 \pm 0.39$ & $3.18 \pm 0.36$ & $4.39 \pm 0.45$ & $3.06 \pm 0.28$ & $4.59 \pm 0.39$ & $2.76 \pm 0.40$ & $3.5-5.5$ \\
\hline $\mathrm{WBC}\left(\mathrm{mm}^{3}\right)$ & $6.65 \pm 0.55$ & $6.47 \pm 0.72$ & $7.18 \pm 0.60$ & $6.29 \pm 0.49$ & $7.42 \pm 0.55$ & $6.72 \pm 0.67$ & $3.5-10$ \\
\hline Platelets $\left(\mathrm{mm}^{3}\right)$ & $218 \pm 20.5$ & $249 \pm 14.8$ & $259 \pm 30.8$ & $298 \pm 19.5$ & $282 \pm 26.4$ & $328 \pm 20.5$ & $100-400$ \\
\hline $\begin{array}{l}\text { mean platelet } \\
\text { volume (fL) }\end{array}$ & $10.3 \pm 0.18$ & $10.9 \pm 0.62$ & $10.5 \pm 0.31$ & $11.2 \pm 0.35$ & $10.7 \pm 0.20$ & $11.5 \pm 0.40$ & \\
\hline $\begin{array}{l}\text { Platelet distribution } \\
\text { width [\%] }\end{array}$ & $11.3 \pm 0.72$ & $12.3 \pm 0.90$ & $11.6 \pm 0.39$ & $12.5 \pm 0.89$ & $11.9 \pm 0.51$ & $12.7 \pm 0.48$ & \\
\hline
\end{tabular}

Abbreviations: BMI: body mass index; Hb: hemoglobin; HbAlC: glycated hemoglobin; RBC: red blood cells; WBC: white blood cells. 
Table 4. Characteristics of understudy population.

\begin{tabular}{|c|c|c|}
\hline Characteristics & $\%$ of T1DM $(n=84)$ & $\%$ of Ref subjects $(\mathrm{n}=194)$ \\
\hline \multicolumn{3}{|l|}{ Ethnic origin } \\
\hline Sindhi & $77.3(65)$ & $86.6(170)$ \\
\hline Punjabi & $11.90(10)$ & $6.18(12)$ \\
\hline Pathan & $5.9(5)$ & $4.12(8)$ \\
\hline Baloch & $4.76(4)$ & $2.06(4)$ \\
\hline \multicolumn{3}{|l|}{ Socioeconomic status } \\
\hline Poor & $29.7(25)$ & $41.2(80)$ \\
\hline Middle class & $42.8(36)$ & $36.2(70)$ \\
\hline Rich & $27.3(23)$ & $22.6(44)$ \\
\hline \multicolumn{3}{|c|}{ Type of Diabetes in Parents } \\
\hline Type-2 Diabetes & $23.8(20)$ & $38.6(75)$ \\
\hline Gestational Diabetes & $5.9(5)$ & $6.18(12)$ \\
\hline No & $70.2(59)$ & $55.5(107)$ \\
\hline \multicolumn{3}{|l|}{ Schooling } \\
\hline Primary & $35.7(30)$ & $23.1(45)$ \\
\hline Elementary & $22.6(19)$ & $32.9(64)$ \\
\hline No & $41.6(35)$ & $43.8(85)$ \\
\hline \multicolumn{3}{|l|}{ Diet } \\
\hline \multicolumn{3}{|l|}{ Meat } \\
\hline Once a week & $21.4(18)$ & $25.77(50)$ \\
\hline Twice a week & $41.6(35)$ & $18.04(35)$ \\
\hline Once a month & $19.04(16)$ & $33.5(65)$ \\
\hline Twice a month & $11.90(10)$ & $15.46(30)$ \\
\hline Rarely & $5.95(5)$ & $7.21(14)$ \\
\hline \multicolumn{3}{|l|}{ Fruit } \\
\hline Once a week & $9.52(10)$ & $27.8(54)$ \\
\hline Twice a week & $29.7(25)$ & $20.61(40)$ \\
\hline Once a month & $33.3(28)$ & $16.49(32)$ \\
\hline Twice a month & $16.6(14)$ & $20.10(39)$ \\
\hline Rarely & $8.33(7)$ & $14.9(29)$ \\
\hline
\end{tabular}

Key: a Diabetic Mellitus type-1.

\subsubsection{Collection of Scalp Hair Samples}

$5 \mathrm{~cm}$ root of hair taken from the nape of neck were used. The scalp hair samples (approximately $0.5 \mathrm{~g}$ ) were taken from the nape of neck. For each participant, the hair specimen were put individually in tightly sealed plastic bags and attached with identification number and questionnaire. At the time of sample pretreatment, the hair specimens were further cut into 0.2 to $0.3 \mathrm{~cm}$ pieces, and washed four times with 1:2 v/v dilution of Triton X-100, then rinsed three times with ultra-pure water, and two times with acetone. Then at $80^{\circ} \mathrm{C}-85^{\circ} \mathrm{C}$, the hair 
specimens were dried in an oven.

\subsection{Microwave Assisted Acid Digestion}

Replicate six specimen of every certified reference materials, BCR 397 human hair $(0.2 \mathrm{~g})$, Clincheck ${ }^{\circledR}$ control-lyophilized human whole blood, and Clincheck control lyophilized ${ }^{\circledR}$ human serum $(0.5 \mathrm{~mL})$, and duplicate samples of scalp hair $(0.2 \mathrm{~g})$, blood and serum $(0.5 \mathrm{~mL})$ were taken individually in polytetrafluoroethylene (PTFE) flasks ( $25 \mathrm{~mL}$ in volume). Then added $3 \mathrm{~mL}$ of a freshly prepared mixture of concentrated $\mathrm{HNO}_{3}-\mathrm{H}_{2} \mathrm{O}_{2}(2: 1, \mathrm{v} / \mathrm{v})$, kept at room temperature for ten minutes. Then put the flasks in covered PTFE container and heated at $80 \%$ of total power $(900 \mathrm{~W})$ for three or four minutes. $0.2 \mathrm{~mol} / \mathrm{L}$ concentrated $\mathrm{HNO}_{3}$ solution was used for dilution of digested biological samples up to $10 \mathrm{~mL}$. Blank extraction (without sample) was used throughout the whole analysis.

\subsection{Statistical Analysis}

Software packages, Minitab 13.2 (Minitab Inc., State College, PA), Excel 2003 (Microsoft Office ${ }^{\circledR}$ ) and XL State (Addinsoft, NY, USA), were used to conduct data processing and statistical analysis. The analysis of variance was used to evaluate the consequence of alterations among the concentrations of $\mathrm{Cd}$ and $\mathrm{Zn}$ in the biological specimen of T1DM children and control subjects, calculated by the unpaired two-sample t-test. A $p<0.05$ was measured substantial alteration. For the evaluation of the substantial alteration of understudy elements in experimental and certified reference values, Student's t-test was used.

\subsection{Analytical Figures of Merit}

Calibration curve reached from the detection limit up to $10 \mu \mathrm{g} / \mathrm{g}$ for the concentration range of $\mathrm{Cd}$ and $\mathrm{Zn}$. The limit of quantification (LOQ) and detection (LOD) were found as $\mathrm{LOQ}=\frac{10 \sigma}{m}$ and $\mathrm{LOD}=\frac{3 \sigma}{m}$ respectively, where $\sigma$ is the standard deviation of 10 readings of blank $(n=10)$ and $m$ is the slope of the linear section of the calibration graphs. The MAD requires a very short time of 2 - $3 \mathrm{~min}$ to digest the samples. Accuracy and efficiency of the method was checked through certified samples of blood and scalp hair (Table 5). From the certified values, the difference for the mean values of $\mathrm{Cd}$ and $\mathrm{Zn}$ were observed less than $1 \%-2 \%$. $<2 \%$ of the coefficient of variation was observed and by comparing both procedures, non-significant differences $(p>0.05)$ were perceived.

\section{Results}

The anthropometric parameters such as weight, height, body mass index, white blood cells, and red blood cells were significantly lower in T1DM children as compared to control subjects whilst glucose level, glycated hemoglobin, platelets, platelet distribution width and mean platelet volume were higher in T1DM children as compared to control children of both genders. 
Table 5. Determination of $\mathrm{Cd}$ and $\mathrm{Zn}$ in certified samples by microwave digestion method $(\mathrm{N}=6)$.

\begin{tabular}{|c|c|c|c|c|}
\hline Elements & $\begin{array}{l}\text { Certified } \\
\text { values }\end{array}$ & $\begin{array}{c}\text { MWD } \\
\text { Mean } \pm \text { SD }\end{array}$ & (\%) Recovery & $\begin{array}{c}\text { Paired t-test } \\
t^{\mathrm{a}} \\
\mathrm{t}^{\text {Experimental }}\end{array}$ \\
\hline \multicolumn{5}{|c|}{ Certified sample of serum $(\mu \mathrm{g} / \mathrm{l})$} \\
\hline $\mathrm{Cd}$ & $4.60 \pm 1.2$ & $\begin{array}{c}4.56 \pm 0.18 \\
(3.95)^{\mathrm{b}}\end{array}$ & 99.1 & 0.123 \\
\hline $\mathrm{Zn}$ & $2.225 \pm 0.334$ & $\begin{array}{c}2.75 \pm 0.16 \\
\quad(5.81)\end{array}$ & 99.6 & 0.670 \\
\hline \multicolumn{5}{|c|}{ Certified sample of whole blood $(\mu \mathrm{g} / \mathrm{l})$} \\
\hline $\mathrm{Cd}$ & $1.2 \pm 0.4$ & $\begin{array}{l}1.189 \pm 0.10 \\
\quad(8.41)\end{array}$ & 99.1 & 0.00636 \\
\hline $\mathrm{Zn}^{*}$ & $2.27 \pm 0.06$ & $\begin{array}{c}2.19 \pm 0.15 \\
\quad(6.61)\end{array}$ & 96.5 & 0.260 \\
\hline \multicolumn{5}{|c|}{ Certified sample of human hair $(\mu \mathrm{g} / \mathrm{g})$} \\
\hline $\mathrm{Cd}$ & $0.52 \pm 0.024$ & $\begin{array}{c}0.515 \pm 0.042 \\
(8.15)\end{array}$ & 99.04 & 0.145 \\
\hline $\mathrm{Zn}$ & $199 \pm 5.0$ & $\begin{array}{c}197.8 \pm 7.29 \\
(3.68)\end{array}$ & 99.4 & 0.678 \\
\hline
\end{tabular}

${ }^{\text {aPaired }} \mathrm{t}$-test between certified values vs. found values, degree of freedom $(n-1)=5$. tcritical $_{\text {at }}$ as $\%$ confidence limit $=2.57 .{ }^{b}$ Values in parenthesis RSD. ${ }^{*} \mathrm{mg} / \mathrm{l}$.

Some trace elements are nutritionally valuable minerals and required for the development and physiology of the organism. Changes in the trace elements could cause of chronic uncontrolled hyperglycemia. The current hospital-based research is performed to find out the different amount (concentrations) of $\mathrm{Cd}$ and $\mathrm{Zn}$ in all the specimen of blood, scalp hair, and serum of T1DM children (Table 6). The analyzed biological samples categorized according to T1DM, controls, and gender.

The level of $\mathrm{Zn}$ in scalp hair samples of T1DM children of both genders, age ranged (1 - 14) years was found to be lower than referent children. The concentration of $\mathrm{Zn}$ in sera samples of male control subjects, age ranged (1 - 14), was found to be higher at $95 \%$ confidence intervals (CI: $1.28-1.66 \mathrm{mg} / \mathrm{L}$ ) than those obtained in sera samples of T1DM children (CI $0.29-0.67 \mathrm{mg} / \mathrm{L}$ ). The same trend was observed in females. The concentrations of $\mathrm{Zn}$ in blood samples of control children of three age groups was found to be higher (CI: 7.09 - 14.2 $\mathrm{mg} / \mathrm{L}$ ) as compared to the $\mathrm{Zn}$ concentrations, observed in blood specimen of T1DM children (CI: $1.36-3.93 \mathrm{mg} / \mathrm{L})$ of both genders $(\mathrm{p}<0.01)$.

In scalp hair samples of male referent children, the concentrations of Cd were found to be lower $\{(\mathrm{CI}: 0.93-1.18),(\mathrm{CI}: 1.59-1.77),(\mathrm{CI}: 2.25-2.57 \mu \mathrm{g} / \mathrm{g})\}$ in three age groups $(1-5),(6-10)$ and $(11-14)$ years, respectively than those $\mathrm{Cd}$ values observed in T1DM children $(\mathrm{p}<0.001)$. The similar findings were observed in females. The concentration of $\mathrm{Cd}$ in serum samples of male and female control subjects age ranged 1 to 14 years was found to be lower (CI: 0.23 - 0.69 
$\mu \mathrm{g} / \mathrm{L})$ as compared to male (CI: $0.49-0.93 \mu \mathrm{g} / \mathrm{L})$ and female $(0.44-0.90 \mu \mathrm{g} / \mathrm{L})$ T1DM children. The Cd concentrations in the blood specimen of control children of both genders (CI: $2.28-4.07 \mu \mathrm{g} / \mathrm{L}$ ) was significantly lower as compared to the Cd concentrations observed in blood samples of male and female T1DM children (CI: $3.47-6.11 \mu \mathrm{g} / \mathrm{L})(\mathrm{p}<0.01)$. Moreover, a decrease of $\mathrm{Zn} / \mathrm{Cd}$ mole ratios in biological samples of T1DM children of both genders as compared to referent children was observed (Table 7).

Student t-test (unpaired) calculated between all studied groups at different probabilities. The calculated $t$-value exceeds to the critical $t$-value at $95 \%$ confidence intervals, which indicated that the difference among means values of both trace metals ( $\mathrm{Cd} \& \mathrm{Zn})$ in control and T1DM children of both genders exhibited significant differences $(\mathrm{p}<0.001)$.

Table 6. Zinc and Cadmium concentrations in biological samples of referents and Diabetic mellitus type 1 (DM1) children of both genders (mean \pm SD).

\begin{tabular}{|c|c|c|c|c|c|}
\hline \multirow{2}{*}{$\begin{array}{l}\text { Biological } \\
\text { samples }\end{array}$} & \multirow{2}{*}{ Age groups } & Control & $\mathrm{DM}^{*}{ }^{*}$ & Control & $\mathrm{DM}^{*}{ }^{*}$ \\
\hline & & \multicolumn{2}{|c|}{ Male } & \multicolumn{2}{|c|}{ Female } \\
\hline \multicolumn{6}{|c|}{ Cadmium } \\
\hline & $1-5 \mathrm{yrs}$ & $1.05 \pm 0.25$ & $1.75 \pm 0.17$ & $0.96 \pm 0.18$ & $1.69 \pm 0.23$ \\
\hline \multirow{3}{*}{$\begin{array}{l}\text { Scalp hair } \\
(\mu \mathrm{g} / \mathrm{g})\end{array}$} & $6-10 \mathrm{yrs}$ & $1.69 \pm 0.18$ & $2.72 \pm 0.30$ & $1.55 \pm 0.16$ & $2.59 \pm 0.34$ \\
\hline & $11-14$ yrs & $2.40 \pm 0.35$ & $3.79 \pm 0.59$ & $2.29 \pm 0.23$ & $3.65 \pm 0.79$ \\
\hline & $1-5$ yrs & $0.31 \pm 0.05$ & $0.52 \pm 0.05$ & $0.27 \pm 0.07$ & $0.46 \pm 0.03$ \\
\hline \multirow[t]{3}{*}{ Serum $(\mu g / 1)$} & $6-10 \mathrm{yrs}$ & $0.45 \pm 0.08$ & $0.69 \pm 0.11$ & $0.41 \pm 0.05$ & $0.65 \pm 0.08$ \\
\hline & $11-14 \mathrm{yrs}$ & $0.62 \pm 0.12$ & $0.89 \pm 0.07$ & $0.58 \pm 0.08$ & $0.84 \pm 0.14$ \\
\hline & $1-5 \mathrm{yrs}$ & $2.63 \pm 0.52$ & $3.92 \pm 0.49$ & $2.51 \pm 0.45$ & $3.70 \pm 0.51$ \\
\hline \multirow[t]{2}{*}{ Blood $(\mu \mathrm{g} / 1)$} & $6-10 \mathrm{yrs}$ & $3.21 \pm 0.40$ & $4.63 \pm 0.35$ & $2.96 \pm 0.52$ & $4.50 \pm 0.65$ \\
\hline & $11-14 \mathrm{yrs}$ & $3.79 \pm 0.65$ & $5.82 \pm 0.72$ & $3.54 \pm 0.68$ & $5.69 \pm 0.85$ \\
\hline \multicolumn{6}{|c|}{ Zinc } \\
\hline \multirow{3}{*}{$\begin{array}{l}\text { Scalp hair } \\
(\mu \mathrm{g} / \mathrm{g})\end{array}$} & $1-5 \mathrm{yrs}$ & $165 \pm 8.26$ & $53.8 \pm 5.15$ & $152 \pm 7.65$ & $49.5 \pm 3.57$ \\
\hline & $6-10 \mathrm{yrs}$ & $198 \pm 6.19$ & $42.8 \pm 3.22$ & $185 \pm 9.37$ & $40.3 \pm 5.27$ \\
\hline & $11-14 \mathrm{yrs}$ & $239 \pm 7.05$ & $35.8 \pm 4.28$ & $219 \pm 9.15$ & $33.5 \pm 5.02$ \\
\hline \multirow{3}{*}{$\begin{array}{l}\text { Serum } \\
(\mathrm{mg} / \mathrm{l})\end{array}$} & $1-5$ yrs & $1.3 \pm 0.04$ & $0.59 \pm 0.12$ & $1.35 \pm 0.05$ & $0.62 \pm 0.09$ \\
\hline & $6-10 \mathrm{yrs}$ & $1.5 \pm 0.07$ & $0.42 \pm 0.10$ & $1.48 \pm 0.08$ & $0.46 \pm 0.07$ \\
\hline & $11-14 \mathrm{yrs}$ & $1.6 \pm 0.10$ & $0.35 \pm 0.10$ & $1.52 \pm 0.12$ & $0.38 \pm 0.05$ \\
\hline \multirow{3}{*}{ Blood (mg/l) } & $1-5 \mathrm{yrs}$ & $11.5 \pm 2.32$ & $3.45 \pm 0.55$ & $13.2 \pm 1.83$ & $3.75 \pm 0.32$ \\
\hline & $6-10 \mathrm{yrs}$ & $9.35 \pm 0.48$ & $2.09 \pm 0.39$ & $8.92 \pm 0.74$ & $1.96 \pm 0.28$ \\
\hline & $11-14 \mathrm{yrs}$ & $7.85 \pm 1.15$ & $1.65 \pm 0.28$ & $7.58 \pm 0.95$ & $1.48 \pm 0.22$ \\
\hline
\end{tabular}

${ }^{*} \mathrm{p}<0.001$. 
Table 7. Zn/ Cd Mole ratio in biological samples of referents and type 1vDiabetic mellitus (T1DM) children of both genders.

\begin{tabular}{cccccc}
\hline \multirow{2}{*}{ Specimens } & Age groups & \multicolumn{2}{c}{ Male } & \multicolumn{2}{c}{ Female } \\
\cline { 2 - 6 } & $1-5$ & Referent & T1DM & Referent & T1DM \\
\hline \multirow{2}{*}{ Scalp hair } & $6-10$ & 201 & 50.3 & 272 & 52.8 \\
& $11-14$ & 171 & 26.7 & 205 & 27.0 \\
Blood & $1-5$ & 7515 & 15.8 & 164 & 16.2 \\
& $6-10$ & 5006 & 1513 & 9038 & 1742 \\
& $11-14$ & 3559 & 776 & 5179 & 749 \\
& $1-5$ & 7207 & 1950 & 3680 & 447 \\
\hline & $6-10$ & 5729 & 1046 & 8593 & 2316 \\
& $11-14$ & 4435 & 676 & 6204 & 1216 \\
\hline
\end{tabular}

\section{Discussion}

Type 1 diabetes mellitus (T1DM) is a chronic disorder with well-known shortand long-term consequences [28]. One of the long-term consequences is severe impairment of growth and development, the so-called Mauriac syndrome [29]. As a result of the major advances in diabetes care, this entity becomes a gem. Indeed, some studies are reporting during the last decade about the positive growth characteristics in diabetic children [30] [31]. However, growth deceleration during T1DM has been reported in various countries around the world, such as Austria, Brazil, Czech Republic, Germany, and Sudan [32] [33] [34] [35].

The prevalence of childhood overweight and obesity has risen during the last 30 years. Not only in children with type 2 diabetes but also those with type 1 are overweight and obese [36]. In children with type 1 diabetes, obesity is linked to an increased cardiovascular risk [37]. Moreover, the presence of overweight also increases insulin resistance, which can intensify complications of treatment [38]. Anemia is a prevailing symptom in type 1 diabetic patients and expresses a significant non-recognized burden. Patients were at greatest risk to be diagnosed for the presence of renal disease (albuminuria and/or renal impairment) [39]. Although low hemoglobin is generally associated with adverse events in diabetes and kidney disease [40]. Several studies showed that high hematocrit predicted in type 1 and 2 diabetes [41] [42] [43]. However, the reasons for this relationship did not explore.

Type 1 diabetes may cause hyperglycemia (high blood sugar). It is a clear sign that diabetes did not a well-control disorder. The processes of non-enzymatic glycosylation of red cell membranes and cytosol proteins are activated during hyperglycemia. An increase in glycosylated hemoglobin (HbA1c) may affect the efficiency of the oxygen-transport function in RBCs. Whereas, HbAlc enhanced the affinity for $\mathrm{O}_{2}$ to complicate its return to cells in the microcirculation [44]. This may promote the development of tissue hypoxia. There is an enhanced level 
of fetal hemoglobin ( $\mathrm{HbF}$ ) in RBCs under the condition of diabetes. Such changes are compensatory to provide a better supply of oxygen to tissues. Whereas, $\mathrm{HbF}$ can bind oxygen with greater affinity and return it to much less partial pressure [45].

Children with newly diagnosed type 1 diabetes had lower total white blood cell count (WBC), and fewer neutrophils, basophils, monocytes, and lymphocytes than controls. Similar, erythrocyte, eosinophil, and platelet count were also lower. This may be supporting general involvement in the innate immune system in the pathogenesis of type 1 diabetes [46]. Diabetic people have multiple abnormalities to platelet function, usually causing hyper-reactivities such as adhesiveness, activation, and aggregation with a greater extent as compared to those not affected to diabetes. These abnormalities of platelet are associated with increased clotting, impaired clot breakdown, endothelial dysfunction, and platelet hyper-reactivity. This contributes to the increased risk of atherothrombotic events in people with diabetes compared with non-diabetic individuals [47].

The homeostasis of zinc can be disturbed by DM. Zinc plays an important role to correct the function of glucose and lipid metabolism as well as regulating and forming the expression of insulin.

Concerning essential metals/elements, the major clinical attention, and most of the publication focus on the deficiencies of a one or single element or definite combination of elements [48]. In the present study, the concentrations of $\mathrm{Zn}$ and $\mathrm{Cd}$ in biological samples of T1DM children of both genders were determined and then these results were compared with referent children, belonging to different areas of Sindh, Pakistan.

The results explained that the concentration of $\mathrm{Zn}$ was considerably/ significantly lower in scalp hair, serum, and blood samples of T1DM children than referents $(\mathrm{P}<0.001)$. Zn plays an important role in the physiological action of insulin as well as its contribution is also essential for glucose metabolism [49]. Zinc is necessary for many enzymes, which are involved in the biosynthesis and storage of insulin in the B-cells. Insulin is used for the crystallization of the hormone, which is binding to $\mathrm{Zn}$. A study reported lower plasma $\mathrm{Zn}$ levels [50]. The $\mathrm{Zn}$ is necessary for many enzymes, which are involved in the biosynthesis and storage of insulin in the $B$-cells. Insulin is used for the crystallization of the hormone, which is binding to $\mathrm{Zn}$. A study reported lower plasma $\mathrm{Zn}$ levels [50]. Two $\mathrm{Zn}$ ions with hexametric unit [51] are lying at the center of each other. Hence, after a meal, it is believed that the pancreatic $\beta$-cells release enough amount of insulin, which is stored in to permit the adequate release [51]. Animal studies showed that Zn supplements can complete by Metallothionein (MT). In the progression and development of DM, $8 \mathrm{Zn}$ transporter (hZnT-8) is most concerned. It is because of its function in insulin-secretion from pancreatic vesicles [50]. $\mathrm{Zn}$ transporter is the islet-restricted as an applicant of the manager of insulin secretion and storage, eventually leading to DM [50].

The resulted data point out that the biological samples of T1DM children of both genders have significantly higher levels of cadmium (Cd) as compare to 
control children. Cadmium is also present as an impurity in several products, including phosphate fertilizers, detergents, and refined petroleum products. Besides, acid rain and the resulting acidification of soils and surface waters have increased the geochemical mobility of $\mathrm{Cd}$, and as a result, its surface-water concentrations tend to increase as lake water $\mathrm{pH}$ decreases [52].

Cadmium produced as an inevitable byproduct of $\mathrm{Zn}$ and occasionally lead refining. The application of agricultural inputs such as fertilizers, pesticides, and biosolids (sewage sludge), the disposal of industrial wastes or the deposition of atmospheric contaminants increases the total concentration of $\mathrm{Cd}$ in soils, and the bioavailability of this $\mathrm{Cd}$ determines whether plant $\mathrm{Cd}$ uptake occurs to a significant degree [53]. Low doses of Cd used in experiments mimic low or moderate levels of environmental contamination.

The antagonistic effects of $\mathrm{Cd}$ and $\mathrm{Zn}$ intensively investigated. The accumulation of $\mathrm{Cd}$ in the human body may be replaced by $\mathrm{Zn}$ in the arteries to shape the arteries brittle and inflexible [54]. The limited information is available for the impact of $\mathrm{Cd}$ on insulin receptors and insulin action in adipose tissue [55]. The stimulatory consequence of $\mathrm{Cd}$ on glucose transport was confirmed by cell culture model. However, no effects on GLUT4 protein were obvious [56]. The Cd-induced glucose transport mechanism was reported in a vitro study [57], which explained the insulin-mimetic effect of $\mathrm{Cd}$ on glucose lipogenesis and glucose oxidation in rat adipocytes [57].

Low Cd concentration in pancreatic islets of obese hyperglycemic mice evoked basal and glucose-stimulated insulin response [58]. In contrast, high Cd concentration significantly inhibited the secretory response of glucose [58]. In vivo rat intake of $\mathrm{Cd}$ resulted in lower glycemia accompanied by higher serum insulin value [58]. Further discrepancies in Cd effects on glucose homeostasis and insulin levels are results of hyperglycemia and inhibition of insulin release from rat pancreas in rats exposed to cadmium [18].

The pancreas is a glandular organ, which secretes pancreatic juice containing amylase, trypsin, lipase and other digestive enzymes to assist digestion and absorption of nutrients. Researchers found that $\mathrm{Cd}$ exposure decreased the activity of protease in the mouse and inhibited amylase and trypsin activity in the freshwater crab [59] [60]. Besides, ion homeostasis plays a crucial role in toxicosis and nutritional and metabolic diseases in organisms [61]. Abnormal ion homeostasis may induce the abnormal physiological structure and dysfunction of the endocrine gland [62]. Numerous studies showed that heavy metals exerted its toxicity via changing the ion homeostasis in organisms [63] [64]. However, essential elements (such as selenium, zinc) could attenuate $\mathrm{Cd}$ accumulation and has antagonistic effects on apoptosis triggered by $\mathrm{Cd}$ in the pancreas [64].

\section{Conclusions}

It can be concluded that impaired trace-element metabolism may have a key role in the pathogenesis and progression of Type-1 diabetes mellitus. It was observed 
that the concentration of $\mathrm{Zn}$ in blood, scalp hair and serum samples of T1DM male and female children was found to be lower, whilst cadmium concentration was found to be higher than control subject because of insulin deficiency and glucose in tolerance, some dietary \& environmental factor, family history of the T1DM patients, increased urinary excretion of essential trace elements due to poor absorption, disturbances/lack of insulin secretion or its action.

The low level of $\mathrm{Zn}$ was observed in type 1 diabetic mellitus children possibly due to increased urinary excretion of these essential trace elements, and its low uptake in the biological (scalp hair, serum and blood) samples of T1DM children. Higher levels of $\mathrm{Cd}$ with simultaneous lower contents of $\mathrm{Zn}$ may be correlated positively with the end results of diabetic mellitus. The mentioned trace element (zinc) is cofactor of different types of enzymes. The lower levels of zinc in biological samples of T1DM children cause a major role in the etiology of diabetes.

Replacement of zinc deficiency by cadmium, might result in abnormal physiological disorders, as well as other factors, and thus may have a role in T1DM. More studies are needed to find out if the supplementation of zinc in T1DM may help to control diabetes and prevent oxidative injuries leading to diabetic complications.

The assessment of biochemical parameters is also important aspect for confirming the severity of T1DM. It was also observed in the present study that the socioeconomic factors also play a role in higher mortality rates in T1DM children, such as poor nutrition, irregular screening, late diagnosis and unequal access to health care due to poverty, because the cost of T1DM treatment is very high.

\section{Conflicts of Interest}

The authors declare no conflicts of interest regarding the publication of this paper.

\section{References}

[1] Morahan, G. (2012) Insights into Type 1 Diabetes Provided by Genetic Analyses. Current Opinion in Endocrinology, Diabetes and Obesity, 19, 263-270. https://doi.org/10.1097/MED.0b013e328355b7fe

[2] Weets, I., Siraux, V., Daubresse, J.C., De Leeuw, I.H., Fery, F., Keymeulen, B. and Rottiers, R. (2002) Relation between Disease Phenotype and HLA-DQ Genotype in Diabetic Patients Diagnosed in Early Adulthood. Biological Trace Element Research, 87, 2597-2605. https://doi.org/10.1210/jcem.87.6.8613

[3] Witte, K.K., Nikitin, N.P., Parker, A.C., von Haehling, S., Volk, H.D., Anker, S.D. and Cleland, J.G. (2005) The Effect of Micronutrient Supplementation on Quality-of-Life and Left Ventricular Function in Elderly Patients with Chronic Heart Failure. European Heart Journal, 26, 2238-2244.

https://doi.org/10.1093/eurheartj/ehi442

[4] Onkamo, P., Vaananen, S., Karvonen, M. and Tuomilehto, J. (1999) Worldwide In- 
crease in Incidence of Type I Diabetes-The Analysis of the Data on Published Incidence Trends. Diabetologia, 42, 1395-1403.

https://doi.org/10.1007/s001250051309

[5] Lepore, M., Pampanelli, S., Fanelli, C., et al. (1997) Preparing Students with Diabetes for Life at College. Diabetes Care, 20, 577-584.

[6] Eurodiab Ace Study Group (2000) Variation and Trends in Incidence of Childhood Diabetes in Europe. The Lancet, 355, 873-876. https://doi.org/10.1016/S0140-6736(99)07125-1

[7] Sreekanth, R., Pattabhi, V. and Rajan, S.S. (2008) Molecular Basis of Chromium Insulin Interactions. Biochemical and Biophysical Research Communications, 369, 725-729. https://doi.org/10.1016/j.bbrc.2008.02.083

[8] Prabodh, S., Prakash, D.S., Sudhakar, G., Chowdary, N.V., Desai, V. and Shekhar, R. (2011) Status of Copper and Magnesium Levels in Diabetic Nephropathy Cases: A Case-Control Study from South India. Biological Trace Element Research, 142, 29-35. https://doi.org/10.1007/s12011-010-8750-x

[9] Bhatti, M.T., Butt, T. and Qazi, M. (2002) Clinical and Biochemical Features of Diabetic Children at Initial Presentation. Pakistan Pediatric Journal, 26, 195-198.

[10] Osredkar, J. and Sustar, N. (2011) Copper and Zinc, Biological Role and Significance of Copper/Zinc Imbalance. Journal of Clinical Toxicology, S3, 001. https://doi.org/10.4172/2161-0495.S3-001

[11] El Missiry, M., Hamed Hussein, M., Khalid, S., Yaqub, N., Khan, S., Itrat, F. and Faulkner, L. (2014) Assessment of Serum Zinc Levels of Patients with Thalassemia Compared to Their Siblings. Anemia, 2014, Article ID: 125452. https://doi.org/10.1155/2014/125452

[12] Li, B., Tan, Y., Sun, W., Fu, Y., Miao, L. and Cai, L. (2013) The Role of Zinc in the Prevention of Diabetic Cardiomyopathy and Nephropathy. Toxicology Mechanisms and Methods, 23, 27-33. https://doi.org/10.3109/15376516.2012.735277

[13] Kim, J. and Lee, S. (2012) Effect of Zinc Supplementation on Insulin Resistance and Metabolic Risk Factors in Obese Korean Women. Nutrition Research and Practice, 6, 221-225. https://doi.org/10.4162/nrp.2012.6.3.221

[14] Nawrot, T.S., Thijs, L., Den Hond, E.M., Roels, H.A. and Staessen, J.A. (2002) An Epidemiological Reappraisal of the Association between Blood Pressure and Blood Lead: A Metaanalysis. Journal of Human Hypertension, 16, 123-131. https://doi.org/10.1038/sj.jhh.1001300

[15] Mollace, V., Rosano, G.M.C., Anker, S.D., Coats, A.J.S., Seferovic, P., Mollace, R., Tavernese, A., Gliozzi, M., Musolino, V., Carresi, C., Maiuolo, J., Macrì, R., Bosco, F., Chiocchi, M., Romeo, F., Metra, M. and Volterrani, M. (2021) Pathophysiological Basis for Nutraceutical Supplementation in Heart Failure: A Comprehensive Review. Nutrients, 13, 257. https://doi.org/10.3390/nu13010257

[16] Bhattacharyya, M.H., Wilson, A.K., Ragan, S.S. and Jonch, M. (2000) Biochemical Pathways in Cadmium Toxicity. In: Zalups, R.Z. and Koropatnick, J., Eds., Molecular Biology and Toxicology of Metals, Taylor \& Francis, New York, 276-299.

[17] Goyer, R.A. (1997) Toxic and Essential Metal Interactions. Annual Review of Nutrition, 17, 37-50. https://doi.org/10.1146/annurev.nutr.17.1.37

[18] Merali, Z. and Singhal, R.L. (1980) Diabetogenic Effects of Chronic Oral Cadmium Administration to Neonatal Rats. British Journal of Pharmacology, 69, 151-157. https://doi.org/10.1111/j.1476-5381.1980.tb10895.x

[19] Kazi, T.G., Afridi, H.I., Kazi, N., et al. (2008) Distribution of Zinc, Copper and Iron in Biological Samples of Pakistani Myocardial Infarction (1st, 2nd and 3rd Heart 
Attack) Patients and Controls. Clinica Chimica Acta, 389, 114-119. https://doi.org/10.1016/j.cca.2007.12.004

[20] Soylak, M., Elci, L., Divrikli, U., et al. (2001) Monitoring Trace Metal Levels in Kirsehir-Turkey: Serum Copper and Zinc Levels of Healthy Subjects. Fresenius Environmental Bulletin, 10, 329-330.

[21] Saraymen, R., Soylak, M. and Narin, I. (1998) Serum Cadmium Levels of People Living in Kayseri-Belsin Region, Turkey. Fresenius Environmental Bulletin, 7, 403-405.

[22] Rodushkin Idman, F.O., Olofsson, R. and Axelsson, M.D. (2000) Determination of 60 Elements in Whole Blood by Sector Field Inductively Coupled Mass Spectrometry. Journal of Analytical Atomic Spectrometry, 15, 937-944. https://doi.org/10.1039/B003561K

[23] Park, S.B., Choi, S.W. and Nam, A.Y. (2009) Hair Tissue Mineral Analysis and Metabolic Syndrome. Biological Trace Element Research, 130, 218-228. https://doi.org/10.1007/s12011-009-8336-7

[24] Soylak, M., Saraymen, R. and Dogan, M. (1995) Investigation of Lead, Chromium, Cobalt and Molybdenum Concentrations in Hair Samples Collected from Diabetic-Patients. Fresenius Environmental Bulletin, 4, 485-490.

[25] Park, Y. (2006) Why Is Type 1 Diabetes Uncommon in Asia? Annals of the New York Academy of Sciences, 1079, 31-40. https://doi.org/10.1196/annals.1375.005

[26] Wild, S., Roglic, G., Green, A., Sicree, R. and King, H. (2004) Global Prevalence of Diabetes: Estimates for the Year 2000 and Projections for 2030. Diabetes Care, 27, 1047-1053. https://doi.org/10.2337/diacare.27.5.1047

[27] Shera, A.S., Jawad, F. and Basit, A. (2002) Diabetes Related Knowledge, Attitude and Practices of Family Physicians in Pakistan. Journal of Pakistan Medical Association, 52, 465-470.

[28] Daneman, D. (2006) Type 1 Diabetes. The Lancet, 367, 847-858. https://doi.org/10.1016/S0140-6736(06)68341-4

[29] Kim, M.S. and Quintos, J.B. (2008) Mauriac Syndrome: Growth Failure and Type 1 Diabetes Mellitus. Pediatric Endocrinology Reviews, 5, 989-993.

[30] Scheffer-Marinus, P.D., Links, T.P., Reitsma, W.D. and Drayer, N.M. (1999) Increased Height in Diabetes Mellitus Corresponds to the Predicted and the Adult Height. Acta Paediatrica, 88, 384-388. https://doi.org/10.1111/j.1651-2227.1999.tb01126.x

[31] Donaghue, K.C., Kordonouri, O., Chan, A. and Silink, M. (2003) Secular Trends in Growth in Diabetes: Are We Winning? Archives of Disease in Childhood, 88, 151-154. https://doi.org/10.1136/adc.88.2.151

[32] Lebl, J., Schober, E., Zidek, T., Baldis, S., Rami, B., Pruhova, S., Kolouskova, S., Snajderova, M. and Frisch, H. (2003) Growth Data in Large Series of 587 Children and Adolescents with Type 1 Diabetes Mellitus. Endocrine Regulations, 37, 153-161.

[33] Meira Sde, O., Morcillo, A.M., Lemos-Marini, S.H., Paulino, M.F., Minicucci, W.J. and Guerra-Júnior, G. (2005) Pubertal Growth and Final Height in 40 Patients with Type 1 Diabetes Mellitus. Arquivos Brasileiros de Endocrinologia e Metabologia, 49, 396-402. https://doi.org/10.1590/S0004-27302005000300011

[34] Holl, R.W., Grabert, M., Heinze, E., Sorgo, W. and Debatin, K.M. (1998) Age at Onset and Long-Term Metabolic Control Affect Height in Type-1 Diabetes Mellitus. European Journal of Pediatrics, 157, 972-977. 
https://doi.org/10.1007/s004310050980

[35] Elamin, A., Hussein, O. and Tuvemo, T. (2006) Growth, Puberty, and Final Height in Children with Type 1 Diabetes. Journal of Diabetic Complications, 20, 252-256. https://doi.org/10.1016/j.jdiacomp.2005.07.001

[36] Luczynski, W., Szypowska, A., Glowinksa-Olszewska, B. and Bossowski, A. (2011) Overweight, Obesity and Features of Metabolic Syndrome in Children with Diabetes and Treated with Insulin Pumptherapy. European Journal of Pediatrics, 170 , 891-898. https://doi.org/10.1007/s00431-010-1372-7

[37] Valerio, G., Lafusco, D., Zucchini, S. and Maffeis, C. (2012) Abdominal Adiposity and Cardiovascular Risk Factors in Adolescents with Type 1 Diabetes. Diabetes Research and Clinical Practice, 97, 99-104.

https://doi.org/10.1016/j.diabres.2012.01.022

[38] Medeirosda Costa, V., de Carvalho, P.P., Castor Fontes de Lima, G., et al. (2016) Overweight among Children and Adolescents with Type 1 Diabetes Mellitus: Prevalence and Associated Factors. Diabetology \& Metabolic Syndrome, 8, 39. https://doi.org/10.1186/s13098-016-0154-4

[39] Thomas, M., MacIsaac, R., Tsalamandris, C., Molyneaux, L., Goubina, I., Fulcher, G., Yue, D. and Jerums, G. (2004) Anemia in Patients with Type 1 Diabetes. The Journal of Clinical Endocrinology and Metabolism, 89, 4359-4363. https://doi.org/10.1210/jc.2004-0678

[40] Levin, A., Thompson, C., Ethier, J., Carlisle, E., Tobe, S., Mendelsshon, D., Burgess, E., Jindal, K., Barrett, B., Singer, J. and Djurdjev, O. (1999) Left Ventricular Mass Index Increase in Early Renal Disease: Impact of Decline in Hemoglobin. The American Journal of Kidney Diseases, 34, 125-134. https://doi.org/10.1016/S0272-6386(99)70118-6

[41] Perry, I.J. and Shaper, A.G. (1996) Hematocrit and Risk of NIDDM. Diabetes, 45, 576-579. https://doi.org/10.2337/diab.45.5.576

[42] Tamariz, L., Young, H., Pankow, J. and Schmidt, M. (2003) Blood Viscosity Is a Risk Factor for Incident Type 2 Diabetes Mellitus: The Atherosclerosis Risk in Communities Study (ARIC) (Abstract). Diabetes, 52, A230.

[43] Nakanishi, N., Suzuki, K. and Tatara, K. (2004) Haematocrit and Risk of Development of Type 2 Diabetes Mellitus in Middle-Aged Japanese Men. Diabetic Medicine, 21, 476-482. https://doi.org/10.1111/j.1464-5491.2004.01152.x

[44] Samaja, M., Melotti, D., Carenini, A. and Pozza, G. (1982) Glycosylated Haemoglobins and the Oxygen Affinity of Whole Blood. Diabetologia, 23, 399-402. https://doi.org/10.1007/BF00260950

[45] Choi, J.W., Nahm, C.H. and Lee, M.H. (2011) Relationships of Fetal-Type Erythropoiesis versus Nitric Oxide Production and Glycated Hemoglobin Levels in Diabetics. Annals of Clinical \& Laboratory Science, 41, 224-228.

[46] Harsunen, M.H., Puff, R., D’Orlando, O., Giannopoulou, E., Lachmann, L., Beyerlein, A., von Meyer, A. and Ziegler, A.G. (2013) Reduced Blood Leukocyte and Neutrophil Numbers in the Pathogenesis of Type 1 Diabetes. Hormone and Metabolic Research, 45, 467-470. https://doi.org/10.1055/s-0032-1331226

[47] Ferreiro, J.L., Gómez-Hospital, J.A. and Angiolillo, D.J. (2010) Platelet Abnormalities in Diabetes Mellitus. Diabetes and Vascular Disease Research, 7, 4251-4259. https://doi.org/10.1177/1479164110383994

[48] Zargar, A.H., Shah, N.A., Masoodi, S.R., et al. (2002) Copper, Zinc and Magnesium Levels in Type-1 Diabetes Mellitus. Saudi Medical Journal, 23, 539-542. 
[49] Isbir, T., Tamer, L., Taylor, A. and Isbir, M. (1993) Zinc, Copper and Magnesium Status in Insulin-Dependent Diabetes. Diabetes Research, 26, 41-45.

[50] Brun, J.F., Fons, C., Fussellier, M., Bardet, L. and Orsetti, A. (1992) Urinary Zinc and Its Relationships with Microalbuminuria in Type I Diabetics. Biological Trace Element Research, 32, 317-323. https://doi.org/10.1007/BF02784617

[51] Rutter, G.A. (2010) Think Zinc: New Roles for Zinc in the Control of Insulin Secretion. Islets, 2, 49-50. https://doi.org/10.4161/isl.2.1.10259

[52] Campbell, P.G.C. (2006) Cadmium-A Priority Pollutant. Environmental Chemistry, 3, 387-388. https://doi.org/10.1071/EN06075

[53] Weggler, K., McLaughlin, M.J. and Graham, R.D. (2004) Effect of Chloride in Soil Solution on the Plant Availability of Biosolid-Borne Cadmium. Journal of Environmental Quality, 33, 496-504. https://doi.org/10.2134/jeq2004.4960

[54] Dickel, H., Kuss, O., Schmidt, A. and Diepgen, T.L. (2002) Occupational Relevance of Positive Standard Patch-Test Results in Employed Persons with an Initial Report of an Occupational Disease. International Archives of Occupational and Environmental Health, 75, 423-434. https://doi.org/10.1007/s00420-002-0328-2

[55] Ezaki, O. (1989) IIb Group Metal Ions (Zn2+, Cd2+, Hg2+) Stimulate Glucose Transport Activity by Post-Insulin Receptor Kinase Mechanism in Rat Adipocytes. Journal of Biological Chemistry, 264, 16118-16122. https://doi.org/10.1016/S0021-9258(18)71594-9

[56] Harrison, S.A., Buxton, J.M., Clancy, B.M. and Czech, M.P. (1991) Evidence That Erythroid-Type Glucose Transporter Intrinsic Activity Is Modulated by Cadmium Treatment of Mouse 3T3-L1 Cells. Journal of Biological Chemistry, 266, 19438-19449. https://doi.org/10.1016/S0021-9258(18)55016-X

[57] Yamamoto, A., Wada, O., Ono, T. and Ono, H. (1986) Cadmium Stimulates Glucose Metabolism in Rat Adipocytes. Journal of Inorganic Biochemistry, 27, 221-226. https://doi.org/10.1016/0162-0134(86)80063-0

[58] Nilsson, T., Rorsman, F., Berggren, P.O. and Hellman, B. (1986) Accumulation of Cadmium in Pancreatic Beta Cells Is Similar to That of Calcium in Being Stimulated by Both Glucose and High Potassium. Biochimica et Biophysica Acta, 888, 270-277. https://doi.org/10.1016/0167-4889(86)90225-9

[59] Shimada, H., Funakoshi, T. and Waalkes, M.P. (2000) Acute, Nontoxic Cadmium Exposure Inhibits Pancreatic Protease Activities in the Mouse. Toxicological Sciences, 53, 474. https://doi.org/10.1093/toxsci/53.2.474

[60] Wu, H., Xuan, R., Li, Y., Zhang, X., Wang, Q. and Wang, L. (2013) Effects of Cadmium Exposure on Digestive Enzymes, Antioxidant Enzymes, and Lipid Peroxidation in the Freshwater Crab Sinopotamon henanense. Environmental Science and Pollution Research, 20, 4085-4092. https://doi.org/10.1007/s11356-012-1362-6

[61] Sun, L., Yu, Y., Huang, T., An, P., Yu, D., Yu, Z., Li, H., Sheng, H., Cai, L., Xue, J., Jing, M., Li, Y., Lin, X. and Wang, F. (2012) Associations between Ionomic Profile and Metabolic Abnormalities in Human Population. PLoS ONE, 7, e38845. https://doi.org/10.1371/journal.pone.0038845

[62] Stuss, M., Michalska-Kasiczak, M. and Sewerynek, E. (2017) The Role of Selenium in Thyroid Gland Pathophysiology. Endokrynologia Polska, 68, 440-465. https://doi.org/10.5603/EP.2017.0051

[63] Xi, J., Liu, C.P., Xiao, H.T. and Jing, F. (2016) Effects of Dietary Selenium against Lead Toxicity Are Related to the Ion Profile in Chicken Muscle. Biological Trace Element Research, 172, 496. https://doi.org/10.1007/s12011-015-0585-Z 
[64] Jin, X., Jia, T., Liu, R., et al. (2018) The Antagonistic Effect of Selenium on Cadmium-Induced Apoptosis via PPAR- $\gamma /$ PI3K/Akt Pathway in Chicken Pancreas. Journal of Hazardous Materials, 357, 355-362.

https://doi.org/10.1016/j.jhazmat.2018.06.003 